\title{
A mulher em Angola na literatura colonial de Luís Figueira
}

\author{
Alberto Oliveira Pinto \\ Universidade de Lisboa
}

\begin{abstract}
RESUMO: ENUNCIANDO OS FUNDAMENTOS IDEOLÓGICOS DA LITERATURA COLONIAL PORTUGUESA NAS DÉCADAS DE 1920 E DE 1930, PROCEDE-SE A UM ESTUDO DE CASO DOS ROMANCES DE LUÍS FIGUEIRA, PRINCESA NEGRA (1932) E MIRAGEM AFRICANA (1935), PROCURANDO EVIDENCIAR A UTILIZAÇÃO, NA LITERATURA, DA MULHER ANGOLANA COMO INSTRUMENTO DE COLONIZAÇÃO SEXUAL, DIRECTA OU INDIRECTA, E DA MULHER PORTUGUESA COMO AGENTE DA MISSÃO CIVILIZADORA DO COLONIZADOR.
\end{abstract}

ABSTRACT: ANNOUNCING THE IDEOLOGICAL FOUNDATIONS OF THE PORTUGUESE COLONIAL LITERATURE IN THE 1920S AND 1930S, IT PROCEEDS TO A CASE STUDY OF THE NOVELS OF LUÍS FIGUEIRA, PRINCESA NEGRA (1932) AND MIRAGEM AFRICANA (1935), SEEKING TO DEMONSTRATE THE USE IN LITERATURE, OF ANGOLAN WOMEN AS SEXUAL TOOL OF COLONIZATION, DIRECTLY OR INDIRECTLY, AND THE PORTUGUESE WOMAN AS AN AGENT OF THE CIVILIZING MISSION OF THE COLONIZER.

PALAVRAS-CHAVE: LITERATURA COLONIAL; LUÍS FIGUEIRA; ANGOLA; MULHER. KEYWORDS: COLONIAL LITERATURE; LUÍS FIGUEIRA; ANGOLA; WOMEN. 


\section{A génese da literatura colonial portuguesa em 1925 e os seus funda- mentos ideológicos}

literatura colonial pode ser definida em duas acepções. Uma objectiva ou lata, outra subjectiva ou restrita. De uma perspectiva objectiva, é literatura colonial aquela que, versando sobre os espaços e/ou os povos colonizados e independentemente da vontade, da sensibilidade e dos sentimentos dos seus autores, foi utilizada como veículo de propaganda colonial, ou seja, como legitimação ideológica do facto colonial. De uma perspectiva subjectiva, isto é, tendo em conta a sensibilidade e os sentimentos do autor da obra literária, é literatura colonial apenas aquela literatura que, versando sobre uma realidade colonial, é produzida por alguém que se identifica com o colonizador.

Em ambos os casos, sublinhe-se, encontramo-nos perante a utilização política de obras literárias como instrumentos de propaganda colonial. Eis a razão pela qual tal literatura foi escassa e praticamente ignorada em Portugal até 1924, ano da criação, ainda na vigência da $1^{a}$ República, da Agência Geral das Colónias (mais tarde, já na década de 1950, chamada Agência Geral do Ultramar), primeiro organismo de propaganda colonial neste país, manifestamente tardio, se comparado com os seus congéneres europeus. A literatura colonial portuguesa só veio, portanto, a ser verdadeiramente impulsionada depois da criação, por via da Agência Geral das Colónias, do seu Boletim mensal (chamado Boletim da Agência Geral das Colónias entre 1925 e 1932, Boletim Geral das Colónias entre 1932 e 1957 e Boletim Geral do Ultramar entre esta data e 1974), e sobretudo depois de instituído o Concurso de Literatura Colonial em 1926 (PINTO, 2002).

As ideias base nas quais assentaria o espírito da literatura colonial portuguesa foram gizadas ainda no ano de 1925 pelo historiador Armando Zuzarte Cortesão (1891-1977), agente geral das colónias, em Editorial do primeiro número do Boletim da Agência Geral das Colónias que, por inerência, dirigia (CORTESÃO, 1925), e pelo escritor Carlos Selvagem (1890-1973), em conferência proferida no Salão de Conferências da União Intelectual Portuguesa a 18 de Julho do mesmo ano, sob o título "Literatura Portuguesa de Ambiente Exótico", mas só publicada no Boletim da Agência Geral das Colónias já em 1926, no mesmo número onde se anuncia a abertura da primeira edição do Concurso de Literatura Colonial (SELVAGEM, 1926). Ambos encaram a literatura colonial, associada à propaganda colonial, como uma missão nacional portu- 
guesa, identificando o conceito de raça com o de nação, e ambos exaltam a ideia da interdependência entre o enaltecimento das virtudes civilizadoras dos colonizadores portugueses e a inferiorização dos africanos, apelando para o darwinismo social na definição dos últimos, que designam por "indígenas", como seres humanos em estado de evolução.

Carlos Selvagem, porém, é mais incisivo. Ao afirmar categoricamente que o exotismo português deve, por um lado privilegiar os colonos como protagonistas das obras literárias, por outro evidenciar igualmente o que designa por "os hábitos, a moral, as estranhas e picarescas tradições, as antiquíssimas e ingénuas legendas dos indígenas, a sua mentalidade primitiva, o seu folclore, a sua história oral, os seus mistérios religiosos, a sua candidez nativa de raças escravas [sublinhado nosso]" (Sic) (SELVAGEM, 1926), ele define as duas vertentes que de futuro a literatura colonial portuguesa assumiria: em primeiro lugar, a que se prende com a exaltação dos feitos do homem branco no continente africano e que poderíamos designar, com David Spurr, por transição da vigilância para a afirmação (SPURR, 1993:13-41 e p. 109-124), com Salvato Trigo por passagem do exotismo estético para o exotismo ideológico (TRIGO, s. d. :132-133) e com Bernard Mouralis por exotismo da diferença negativa (MOURALIS, 1982:71-173); em segundo lugar, a da aproximação cultural, ainda que paternalista, do homem europeu ao homem africano, que Spurr designa por operações de apropriação e de estetiaçăão (SPURR, 1993:28-42 e p. 43-60) e Mouralis por exotismo da diferença positiva (MOURALIS, 1982:71-173).

Mas Carlos Selvagem, ao atribuir o motivo da escassez de obras de carácter exótico em Portugal ao flagelo da reputação da África, sobretudo de Angola, como terra do degredo e das ambições desmedidas, vai igualmente denunciar a colonização penal e a especulação dos aventureiros, antecipando-se ao que o seu confrade e amigo Henrique Galvão (1895, Barreiro/Portugal - 1970, São Paulo/Brasil), já em 1929, designaria, recorrendo à mitologia grega clássica e concretamente aos mitos, respectivamente, de Teseu e de Ariadne e de Jasão e dos Argonautas, por "Colónia do Minotauro de Creta" e por "Colónia do Velo de Oiro” (GALVÃO, 1929). Preconizando para Angola uma colonização de povoamento europeu, Galvão viria a combater veementemente tais mitos, quer no seu primeiro livro, Em terra de pretos. Crónicas de Angola, publicado em 1929, quer nos seus romances $O$ vélo d'oiro e $O$ sol do trópicos, publicados, respectivamente, em 1933 e em 1936, e premiados em edições do Concurso da 
Agência Geral das Colónias posteriores ao Acto Colonial de 1930, diploma com força constitucional que regularia a política colonial portuguesa do Estado Novo até 1951 (PINTO, 2002), quer ainda em múltiplas conferências e artigos publicados até ao eclodir da II ${ }^{a}$ Guerra Mundial, em 1939.

Por este motivo, nas obras de literatura colonial portuguesa premiadas pela Agência Geral das Colónias entre 1926 e 1939, no que diz respeito à temática das relações entre europeus e africanos, vai prevalecer, conciliada com a retórica da "diferença negativa", a perspectiva darwiniana mistófoba, isto é, adversa às misturas entre indivíduos de "raças diferentes", tidas por geradoras da degeneração e de um pretenso retrocesso cultural - por contraposição à mistófila, igualmente darwinista, simpatizante das misturas de "raças" nos casos em que estas pudessem conduzir a um "aperfeiçoamento" das ditas "raças" ou mesmo à criação de "novas raças" e "novas civilizações" (TAGUIEFF, 1990), que só muito mais tarde, em 1951, o luso-tropicalismo recuperaria -, a qual se traduz, literariamente, por quatro operações directamente ligadas ao género das personagens romanescas: o clássico enselvajamento do homem africano; a anatemização, quer do mestiço, quer do seu progenitor, o cafrealizado, ou seja, o europeu que assumiu os valores e os costumes atribuídos aos africanos, coabitando com mulheres africanas; a repugnância e abjecção pela mulher africana e a sua transformação, de instrumento de colonização sexual directa (ou hibridística), em instrumento de colonização sexual indirecta; finalmente a exaltação, ainda que tímida, das virtudes e da sensualidade da mulher europeia.

Os elementos ideológicos da literatura colonial portuguesa produzida entre 1926 e 1939 são, em conclusão, essencialmente três: a missão civilizadora, a diferença do Outro na acepção "negativa" e "positiva" e a denúncia da colonização penal e especulativa. Os três vão dar origem às quatro operações retóricas de mistofobia. Como vão perpetrar-se estas quatro operações no discurso narrativo, particularmente no que diz respeito à presença da mulher, africana ou europeia, em Angola?

\section{Luís Figueira e a colonização sexual indirecta em Princesa negra}

Um excelente objecto de estudo de caso para responder à questão que levantámos é a obra literária de Luís Figueira, escritor cujos romances colo- 
niais, de temática angolana, rivalizaram durante a década de 1930 com os de Henrique Galvão.

Luís Maria Figueira (Lisboa, 1898-1973) viveu muitos anos em Angola como comerciante e proprietário agrícola, fixando-se no Lobito e distinguindo-se no jornalismo local (GOMES e CAVACAS, 1997:228), sendo autor dos romances Princesa negra. O preço da civilização em África, publicado em 1932 e galardoado com o $2^{\circ}$ Prémio na $1^{\text {a }}$ Categoria do Concurso de Literatura Colonial de 1933, e Miragem africana. O preço da civilização em África, publicado em 1935. A coincidência do subtítulo nos dois romances, "O preço da civilização em Africa”, apela, desde logo, para a importância que o autor atribui à missão civilizadora dos portugueses no continente africano. No prólogo do seu segundo romance, Miragem Africana. O preço da civilização em África, texto que intitula "Antes do entrecho", Luís Figueira manifesta o seu duplo propósito de, por um lado, exaltar a obra do colono português, e de, por outro lado, caracterizar com rigor os costumes do colonizado angolano, num exotismo estético onde a "diferença negativa" e a "diferença positiva" em relação ao africano parecem entrecruzar-se (FIGUEIRA, 1935:5-9). O mesmo, aliás, já acontecera no "Prólogo" de Princesa negra, onde incluía igualmente notas importantes acerca da execração da eterna ilusão do enriquecimento fácil em Angola, o mesmo flagelo que Henrique Galvão, utilizando o campo semântico da mitologia grega, designara por "Velo de Ouro", e a que Figueira, de modo mais prosaico, chama "miragem africana", que virá a ser, de resto, a temática e o título do seu segundo romance (FIGUEIRA, 1932:7-8).

No que diz respeito às operações retóricas de mistofobia, as obras de Luís Figueira, ao contrário das dos seus congéneres, primam pela ausência total dos mestiços e dos cafrealizados, assim como da dos africanos letrados, os chamados "assimilados", pelo que os angolanos são todos encarados como "indígenas" para cuja caracterização do estádio de selvajaria se privilegiam os processos de retórica colonial do belicismo e do animismo dos africanos. No seu primeiro romance, Princesa negra. O preço da civilização em África, Luís Figueira é mesmo inovador na literatura colonial portuguesa referente a Angola, ao introduzir o argumento da colonização sexual indirecta. De que trata este livro?

Princesa negra. O preço da civilização em África narra na primeira pessoa a história de Ângelo da Assunção Ferraz, um jovem natural do Porto e residente em Lisboa que decide, em 1913, deixar a mãe e a noiva para partir para Angola a 
fim de fazer fortuna como comerciante do mato. Instala-se por conta própria no leste de Angola, no então distrito do Moxico, nas proximidades da Capitania-Mor dos Luchazes, algures nas margens do rio Luanguinga, em terra dos ganguélas, nos quais se integram os bundas, o subgrupo étnico angolano mais tratado no romance. Ângelo Ferraz depressa se tornou conhecido entre os bundas, com quem permutava têxteis por borracha, pelo nome de Marite, por alusão à arma de fogo em cujo manejamento era dextro, sendo por eles visto como um "feiticeiro". E em 1916 consegue conquistar a amizade do soba local, Muêne-Chiputa, abastecendo-o de armas e de pólvora, assim como o amor e o afecto da sua sobrinha e herdeira, a princesa Mutango, a quem fornece roupa feminina ocidental na convicção de, por essa via, "civilizar" uma "selvagem" (FIGUEIRA, 1932:33 e p. 62-63). Não tarda a deflagrar, em Junho do mesmo ano de 1916, a revolta que os bundas, descontentes com a dupla tributação do imposto indígena e privados dos lucros outrora obtidos com o comércio da borracha, agora em decadência, moveram contra os portugueses, massacrando grande número de comerciantes, num conflito sangrento que viria a prolongar-se até Abril do ano seguinte (PÉLISSIER, 1986b:132-139 e p. 329-331). Ao longo da narrativa, a "princesa negra" Mutango salva por duas vezes da "selvajaria" dos seus compatriotas bundas o seu "civilizador" português, o comerciante Ângelo Ferraz/Marite, ambas em Setembro de 1916. Numa primeira ocasião deslocando-se à sua loja e aconselhando-o a fugir perante a iminência de um ataque de guerreiros do seu próprio tio (FIGUEIRA, 1932:76-77). De outra feita, pouco tempo volvido, quando o jovem comerciante, depois de errar vários dias pelo mato, é inadvertidamente capturado por guerreiros bundas que o amarram a um mastro e o condenam à morte (FIGUEIRA, 1932:121-147).

Ângelo Ferraz reencontra então a "princesa negra" em vários momentos que misturam na figura desta mulher angolana - cuja feminilidade, aos seus olhos, reside essencialmente numa astúcia e sagacidade que tanto podem ser benéficas como perversas, inclusive traiçoeiras -, um misto de atracção e de repulsa. Inicialmente ela finge torturá-lo através de uma dança macabra, mas não consegue dissimular um olhar de ternura. Depois, durante a noite, além de o obrigar a ingerir alimentos que lhe repugnam, com o fim de lhe restituir as forças, agasalha-o com uma manta de casca de árvore, resguardando-o do frio, e promete-lhe voltar já de madrugada. Volta efectivamente, depois 
de haver adormecido os guardas com um pó mágico, e conduz então Ângelo/Marite a um cemitério bunda, onde ninguém ousa entrar. Finalmente, ao entregar-lhe uma carabina e a respectiva cartucheira, não só o aconselha a seguir para o posto da Cangamba, ao encontro do capitão-mor Dias Antunes, chefe das milícias armadas portuguesas, como lhe confessa que não aprova a atitude do seu tio e dos demais sobas bundas ao sublevarem-se contra os brancos, que considera protectores e pacificadores (FIGUEIRA, 1932:153177). Meses mais tarde, num período em que os chefes bundas insurrectos já se encontravam, na maioria, dominados pelos militares e comerciantes portugueses, Ângelo Ferraz, participando no ataque ao acampamento de um dos últimos recalcitrantes, um tal Muêne Pembe, poupa-lhe a vida por saber que se trata do noivo da princesa Mutango (FIGUEIRA, 1932:243-257) e vem, inclusivamente, a apadrinhar o seu casamento (FIGUEIRA, 1932:259-285), contanto que doravante o casal constitua um exemplo de vassalagem e fidelidade ao colonizador.

Se o exotismo deste romance de Luís Figueira assenta sobretudo, no que diz respeito à sua visão sobre os angolanos, na "diferença negativa", também nele interfere a "diferença positiva", quer nos momentos em que os "Maus Selvagens" se transformam em "crianças grandes" submissas, isto é, quando os angolanos capitulam perante os portugueses e lhes prestam vassalagem, quer nos momentos em que o autor introduz o argumento de retórica da colonização sexual indirecta. É neste ponto, aliás, que Luís Figueira se revela um escritor original. Tal como Henrique Galvão, o autor de Princesa negra manifesta repugnância pela mulher angolana e questiona a existência da sua "alma". No entanto, se para Galvão o colonizador português deve desprezar a mulher africana, para Figueira, pelo contrário, deve servir-se dos seus eventuais sentimentos "primitivos" e utilizá-los como caminho para alcançar os seus propósitos de domínio. Luís Figueira desenvolve assim, consideravelmente, uma nova categoria de colonizados, a da heroína africana, personificada em Mutango. O que diferencia Mutango de outras mulheres angolanas suas antecedentes na literatura colonial é o facto de, embora apaixonando-se por um português, não lograr desposá-lo porque ele a rejeita. Ângelo Ferraz/ Marite recusa veementemente a cafrealização que resultaria do casamento com uma "princesa negra", preferindo "acasalá-la" com um soba vencido, e assegurando assim a sua dominação de colonizador. Se os cafrealizados eram, 
na viragem do século XIX para o século XX, colonizadores que exerciam directamente a colonização sexual, coabitando com mulheres africanas e gerando filhos mestiços, agora, no primeiro quartel do século XX, Ângelo Ferraz/ Marite, personagem de Luís Figueira, exerce-a indirectamente.

\section{A introdução na literatura colonial portuguesa do estereótipo da mu- lher europeia perdida no caos africano}

Mas Ângelo Ferraz, protagonista e narrador de Princesa Negra, não consegue, no início da década de 1920, encontrar uma companheira branca em Angola. Por isso tem necessidade - valendo-lhe os recursos financeiros de que aufere, depois de criar uma propriedade agrícola no Chinguar, no distrito do Bié - de ir buscá-la à metrópole, à sua terra natal (FIGUEIRA, 1932:341424), facto inédito, premonitório da colonização familiar de povoamento. Luís Figueira, aliás, serve-se desta ideia como ponto de partida para o seu segundo romance, Miragem africana. O preço da civilização em África, narrativa onde as aventuras são protagonizadas, não por um solitário como Ângelo Ferraz, e sim por um jovem casal de portugueses, Josefina e José Augusto Figueiredo. Ambos naturais da Beira Baixa e residindo inicialmente na Catumbela, vila situada a 12 quilómetros a sul do Lobito e a cerca de 40 a norte de Benguela, onde se haviam instalado ao fim de apenas três meses de casamento, José e Josefina acabam, após múltiplas aventuras pelo sertão angolano, por se fixar no Bailundo, no planalto central, como agricultores. Apesar de o tempo diegético de Miragem africana, o ano de 1914, anteceder em dois anos o de Princesa negra - pelo que depreendemos do relato de uma personagem que diz ter sido vítima da rebelião do Bailundo de 1902 ocorrida cerca de doze anos antes (FIGUEIRA, 1935:145) -, podemos entender este segundo romance de Luís Figueira como uma continuação, decerto autobiográfica, do anterior.

Tal como em Princesa negra, o narrador é um jovem colono português, José Augusto Figueiredo. Mas agora, em contrapartida, a heroína não é uma mulher angolana e sim uma portuguesa, Josefina, a sua esposa. Este facto não é inédito na literatura colonial portuguesa, se o compararmos com os de duas personagens femininas de Henrique Galvão suas contemporâneas: Estela em O velo d'oiro (GALVÃO, 1933) e Marta em O sol dos trópicos (GALVÃO, 1936). 
Mas o que diferencia a personagem de Luís Figueira das de Henrique Galvão é que, ao contrário destas, Josefina não é uma vítima dos maus tratos dos europeus "cafrealizados" (Estela é uma órfã de colonos violentada aos quinze anos de idade pelo comerciante do mato que a recolhe, e Marta quase sucumbe às sevícias do marido e do amante, mais uma vez dois comerciantes do mato), e sim um permanente alvo potencial da "selvajaria" dos africanos. Além disso, Josefina, sendo a imagem da mulher civilizadora, representa desde o início da narrativa a verdadeira companheira do protagonista, o seu duplo, espelhando permanentemente, de uma perspectiva feminina, o olhar do narrador, seu marido, sobre os espaços e os homens africanos.

José, que passara por Angola antes da esposa e que, tal como o seu émulo Ângelo Ferraz, a vai buscar à metrópole, manifesta-se desde logo, à semelhança do que vai sendo cada vez mais frequente entre os colonos, plenamente convicto, quer da ascensão social que representa para uma mulher portuguesa tornar-se mãe de família numa realidade colonial como a angolana, quer da importância do seu papel como civilizadora, submetendo os africanos ao estatuto de serviçais:

Oriunda da Beira Baixa, como eu, Josefina é saudável. As febres ainda não tinham entrado com ela, graças aos meus conhecimentos da vida africana, mormente em climas insalubres como este. [...] Além disso, a vida em África é mais fácil! Há criados para tudo! São baratos. Os pretos aprendem depressa as lides caseiras, os afazeres domésticos... [...] Cada casal tem, pelo menos, um cozinheiro e o seu ajudante; [um] criado para lavar a louça e outro que serve à mesa. O que arruma, lava a casa e faz as camas. O aguadeiro e ainda o criado aprendiz, o auxiliar ou rapaz dos recados (FIGUEIRA, 1935:21).

Num baile organizado pela elite britânica residente no Lobito, Josefina, a mulher portuguesa, emparceira com as suas congéneres inglesas e evidenciase mesmo, pela sua graciosidade, em relação a elas:

Josefina dança, diverte-se. Seu tipo moreno, de cabeleira negra, da cor dos olhos, fazem os ingleses ter por ela especial atenção. O colo de garça, o corpo coleante, bem talhado, tornam-na, realmente, um tipo interessante de portuguesa! (FIGUEIRA, 1935:33). 
Embora reconheça que a maioria dos portugueses ainda julga as suas mulheres incapazes de se adaptarem à vida no continente africano, José ousa levar Josefina, que faz questão de o acompanhar, numa expedição que empreende durante meses pelo mato, na ilusão de vir a encontrar diamantes nas margens do rio Luiana, um afluente do Cuando, no sudeste angolano. Durante a viagem, a conduta corajosa de Josefina evoca um estereótipo feminino muito mais frequente na literatura colonial britânica do que na portuguesa, patenteado, nomeadamente, na sua indumentária:

[...] arma de correia ao ombro, cartucheira a tiracolo, - tal qual guerreiro branco, de feições imberbes, delicadas, cabeleira enrolada atrás da cabeça, debaixo do chapéu à expedicionário, de abas largas! [...] vestida de calções de caqui, camisa do mesmo tecido, botas altas, capacete colonial! - o traje cinegético, próprio de andar no mato! (FIGUEIRA, 1935:163 e p. 173-174).

Josefina é, portanto, na literatura colonial portuguesa, das primeiras mulheres, senão mesmo a primeira, ainda que ao lado do marido, a assumir um papel até então exclusivamente atribuído aos homens: o do explorador europeu que desbrava a natureza inóspita e caótica do continente africano e se reivindica o único - por contraposição aos africanos, considerados "selvagens" - capaz de lhe incutir a ordem e impor a civilização. No que diz respeito à natureza africana, particularmente à fauna, Josefina, revelando porventura uma peculiar sensibilidade feminina, antecipa estranhamente, no primeiro quartel do século XX, um espírito quase ecológico, ao manifestar, por duas vezes, o desejo de acompanhar o marido nas expedições de caça a fim de ver vivos, no seu habitat, os animais ferozes:

Não fui contigo e logo mataram dois leões! Gostava tanto de os ver vivos no mato! [...] Vou farta de andar de tipóia! Quero ir contigo a pé, que melhor verei os animais em vida! Os rinocerontes vi-os, mas depois de mortos!” (FIGUEIRA, 1935:203 e p. 218).

Em contrapartida, no que toca ao seu olhar sobre o homem africano, Josefina mais não é do que o corifeu das perspectivas darwinistas sociais perfilhadas pelo marido. Perante o interesse antropológico que José revela ao 
querer assistir às exéquias de um soba do Bailundo para, como confessa, "conhecer os seus [dos africanos] costumes que tendem a desaparecer pela nossa intervenção de civilizados” (Sic.), a esposa não hesita em classificar tais cerimónias como "fantochadas dos pretos" (FIGUEIRA, 1935:83). Noutro momento, quando José, uma vez informado acerca do sistema económico de recolecção em que vive o povo koi-san - chamado pelos holandeses hotentotes ou huttenhute, isto é, os gagos ou "os que falam aos soluços", ou bushman, os homens dos bosques (M'BOKOLO, 2003:494), de onde derivou o termo português boximane -, evoca o próprio Darwin e põe em causa a teoria segundo a qual o homem descenderia do macaco, admitindo uma hipótese inversa, a de o macaco descender do homem, Josefina é a primeira a apoiar-se no evolucionismo biológico preconizado pelo naturalista britânico:

“- Cala-te homem... cala-te que é preferível!

[...] O macaco, mesmo sendo inteligente, não pensa nem raciocina: imita, não inventa! [afirma José]

- Os boximanes são quase a mesma coisa!... [replica Josefina]” (FIGUEIRA, 1935:210).

De igual modo, Josefina adere plenamente ao clássico topoi ou processo de retórica de enselvajamento, já introduzido por autores europeus do século XIX, tais como Lazlo Magyar, que, atribuindo uma indolência atávica aos homens africanos que os torna socialmente inúteis, se mostram, em contrapartida, complacentes com as mulheres africanas, reconhecendo-lhes o mérito de produtoras de alimentos ao ser-lhes confiado, nas suas sociedades tradicionais, o trabalho da terra (HENRIQUES, 2003:130):

- Pobres mulheres... Elas são obrigadas a sustentarem os vadios, os malandros dos homens! [...] Pois está claro: em toda a parte a mulher é a escrava, a oprimida (FIGUEIRA, 1935:262-263).

Mas Josefina pretende ser, acima de tudo, a civilizada e a civilizadora em Angola, admirando, como modelo, uma das escassas esposas portuguesas dos colonos do Bailundo: 
- A D. Francisca é mulher educada! [...] Vive aqui há sete anos... A mulher ajuda imenso o marido nos serviços agrícolas... E, olha, foi educada no Bom Sucesso... [...] Toca muito bem piano e prometeu-me música quando lá formos (FIGUEIRA, 1935:65).

É, aliás, nessa qualidade de esposa ideal, que Josefina consegue dissuadir o marido da "miragem africana", isto é, da ilusão de buscar o lucro fácil na procura de diamantes, e convencê-lo a fixar-se como agricultor:

- Talvez tivéssemos melhor futuro continuando a dedicar-nos à terra! (FIGUEIRA, 1935:125).

\section{O discurso colonial do rapto da mulher branca em Miragem Africana}

Miragem africana de Luís Figueira introduz igualmente na literatura colonial portuguesa um elemento de retórica que na literatura britânica remonta ao século XVII, se nos lembrarmos que ele já é utilizado em $A$ tempestade, peça de Shakespeare escrita em 1610: o do rapto da mulher branca pelo selvagem e da tentativa de violação de que o europeu o acusa (BONNICI, 2000:57). Se Próspero acusa Caliban de haver tentado raptar e violar a sua filha Miranda (SHAKESPEARE, s.d.:26), José Augusto Figueiredo, protagonista e narrador de Miragem africana, vive momentos dramáticos e tormentosos quando a sua esposa, Josefina, é raptada por "indígenas" angolanos (FIGUEIRA, 1935:264-317). Tal como acontece na literatura colonial britânica, nomeadamente na respeitante ao caso indiano, o discurso colonial do rapto da mulher branca surge em Miragem africana num período em que o domínio do colonizador português em Angola se encontra ameaçado - o tempo diegético do romance, o ano de 1914, é o da revolta de Buta no Kongo e da rebelião do Libolo oriental, seguindo-se ao da revolta de Caculo Cahenda nos Dembos e preparando, quer as sublevações de Sihetekela e de Mandumbe no Cuamato e no Cuanhama, quer a insurreição dos bundas, tratada por Luís Figueira no romance anterior (PÉLISSIER, 1986b:324-333) - e, além de constituir uma legitimação lógica da "missão civilizadora", porquanto contribui para a 
evidenciação da mulher europeia em relação à africana, projecta igualmente as fantasias do homem europeu acerca da sexualidade "selvagem" do Outro (SHARPE, 1993:1-15).

Quem ordena o rapto de Josefina é Capitango, comerciante do mato quimbundo cuja descrição faz lembrar a dos ambaquistas (aportuguesamento do quimbundo muku a mbaka, pl. aku a Mbaka, literalmente gente de Ambaca), a quem o conhecimento da língua portuguesa e da escrita permitiu, nos séculos XVIII e XIX, dedicarem-se ao comércio no sertão angolano, transaccionando com os sobas mercadorias europeias ou americanas vindas da costa, tais como têxteis, espingardas, tabaco, sal, aguardente e gado bovino, em troca sobretudo de escravos ou, à medida que estes, ao longo da segunda metade do século XIX, foram sendo substituídos pelo chamado "comércio lícito", de marfim, cera e borracha. Também transaccionavam cobre do Katanga, esteiras de mabela e azeite de palma oriundo da área kongo e os seus itinerários não se restringiram ao corredor do Cuanza nem às regiões nordestinas Imbangala e Lunda, abrangendo também os sobados dos planaltos centrais do Bié e do Huambo (HEINTZE, 2004:256-257). Ainda que Capitango pudesse ser um ambaquista ou um quimbari - guia de caravana descendente de escravos forros -, de entre os muitos que faziam questão de ser considerados ambaquistas (HEINTZE, 2004:242), o autor não utiliza em nenhum ponto do seu texto tais expressões para o classificar, decerto porque ao tempo em que redige o romance, a década de 1930, ambas já se encontravam anatemizadas em Angola, quer em consequência da política repressiva de Norton de Matos, quer por efeito da atitude auto-silenciadora que os próprios ambaquistas vinham progressivamente adoptando desde finais do século XIX (PINTO, 2006). Luís Figueira opta por descrever Capitango através do recurso ao racialismo do darwinismo social, o qual utiliza como principal motivador da "má selvajaria" da personagem, seja na sua cupidez, seja na sua lubricidade, seja ainda na sua falsa subserviência aos europeus:

Capitango é um homem dos seus cinquenta anos. Alto, musculado, perfeito tipo dos quimbundos antes da mistura de raças raquíticas. [...] Inteligente, nasceu com o condão do negócio, como em regra geral o possuem os da sua tribo. [...] Conseguiu acumular riqueza! $\mathrm{Na}$ sua libata vive em meio de um número respeitável de concubinas! [...] Distribuiu chorudos alembamentos pelos parentes das mulheres! Tem feito inúmeras viagens às longínquas paragens do sertão 
desde os belos tempos da mocidade! Nessas jornadas contraiu amizades entre os diversos chefes negros! Conhece o interior, desde o rio Cubango, ao Sul, aos confins da Lunda, do Cassai, ao Norte! [...] Ambicioso, obedece subserviente aos brancos, no intuito de arranjar prestígio nos conterrâneos, conseguir melhores negócios, mais haveres! (FIGUEIRA, 1935:116).

Todo o enredo do romance assenta sobre o ludíbrio que Capitango exerce sobre José de Figueiredo desde o dia em que, passando com a sua caravana pela Catumbela, lhe vende um diamante que diz ter encontrado no rio Luiana, no distrito do Cuando Cubango, no sudeste angolano. Na realidade Capitango obtivera a pedra preciosa muito mais a norte, na Lunda, onde, por ironia, três anos depois seria fundada, com capitais belgas, portugueses, britânicos, norteamericanos e sul-africanos, a Companhia de Diamantes de Angola "Diamang". É na ilusão de virem a descobrir diamantes no Luiana que José e Josefina atravessam o território de Angola, acompanhando uma expedição comandada pelo próprio Capitango. Depois de uma longa viagem, José de Figueiredo encontra, instalado numa ilha do rio Cuando, o soba Canásse, chefe quiôco fugido aos colonos do Chicápa (Lunda), que inicialmente se opõe à presença de brancos no território. José defronta-o e instala uma loja nas margens do Luiana, por meio da qual obtém borracha e marfim das populações locais. Capitango, entretanto, ausenta-se, a pretexto de ir procurar diamantes noutro lugar. Poucos dias depois, voltando de uma caçada, José é surpreendido com a notícia do rapto da sua esposa por homens do soba Canásse. Quem o informa é um empregado chamado António, apelidado de Santomista, nome pelo qual eram conhecidos os raros angolanos que logravam regressar do trabalho forçado em São Tomé, reproduzindo o que testemunhara Sapálo, uma das concubinas de Capitango que não o acompanhara na viagem:

- Foi a mulher do Capitango quem deu pela falta da senhora! [...] Andava no rio quando viu a senhora agarrada, a debater-se nos braços de três malditos quiôcos! Taparam-lhe a boca, abafaram-lhe os gritos! [...] Surgiram mais quiôcos do mato e ela fugiu medrosa, veio prevenir. [...] Os quiôcos querem panos, cobertores... resgate! Tratam bem a senhora (FIGUEIRA, 1935:267).

Indignado, José não desiste de salvar a companheira e embrenha-se durante dias com os seus fiéis pela Ilha das Andúas, as aves sagradas, onde residia 
o soba Canásse. A incursão na ilha apresenta, em contraste com a descrição exótica da beleza das aves, três momentos impregnados de emoção e de expectativa. Num primeiro, José depara com um embrulho de casca de árvore arrastado pela corrente do rio, que verifica conter o cadáver de uma criança deficiente abandonada pelos pais segundo os costumes "selvagens" dos quiôcos (FIGUEIRA, 1935:292-293). Mais tarde, depois de António Santomista desaparecer misteriosamente, os servidores de José mostram-lhe farrapos de pano que ele identifica como sendo vestígios do vestido de Josefina, num lugar onde os rastos no solo parecem indiciar que a arrastaram à força. É nesse preciso instante que José ouve um dos seus homens gritar aflito "Senhor José, venha cá: a senhora está morta!” e faz uma descoberta terrível:

Desvairado, corro de ansiedade. Entre os arbustos vejo estendido um cadáver, embrulhado, amarrado, cingido dos pés à cabeça, por cordas de landobes! Exala cheiro fétido, pouco pronunciado. Nada se enxerga através da manta! Apenas o cheiro, as formas, nos denunciam a existência de corpo humano! É dela, naturalmente - penso acabrunhado perante tudo quando meus olhos vêem! (FIGUEIRA, 1935:302).

Não tendo sequer coragem de desembrulhar o cadáver, José mais se convence que se trata do de Josefina quando encontra, ao seu lado, "[...] um boneco imitando um branco [...]! Sarapintado, vejo-lhe espetada, do lado do coração, uma flecha, em arranhadura imitando golpe fundo! [...] Puxo por ela, sai-me pintada a encarnado com laivos sanguíneos! [...] Malditos negros... Malditos..." (FIGUEIRA, 1935:303).

É indubitável que, para o colonizador português, os angolanos se dividem em "Maus Selvagens" e "Bons Selvagens". "Maus Selvagens” são os que raptaram Josefina e supostamente a violentaram e puseram fim à vida. "Bons Selvagens" são os que acompanham José e se solidarizam com a sua dor, mas também aqueles que... inusitadamente irão "ressuscitar" Josefina! Mas quem serão, de facto, uns e outros?

Depois de saírem da ilha com o cadáver em putrefacção, José e os seus homens avistam, durante a noite, uma fogueira em torno da qual reconhecem António Santomista e alguns homens que julgam ser os raptores de Josefina. Para vingar o "execrando crime", José decide atacá-los. Mas durante a refrega surpreende um vulto que identifica como sendo... Josefina! Os dois caem nos braços um do 
outro, enquanto ao lado, António Santomista, o "Bom Selvagem” que a salvara, sorri prazenteiro. Acompanhado de amigos, disfarçara-se de quiôco rapando o cabelo, e conseguira introduzir-se no acampamento do soba Canásse, matar o soba e libertar Josefina. Confessa, aliás, orgulhoso ao patrão que "São Tomé faz a gente esperta... educa, transforma-nos!” (sic.) (FIGUEIRA, 1935:318).

Josefina informa então o marido de que o cadáver que ele transportava e que tomara pelo dela era, na realidade, o do soba Canásse, que tinha sido o seu raptor por ordem de Capitango, que os traíra, mas lograra fugir. E contalhe as suas aventuras e desventuras, num relato onde reconhece que a grande maioria das atrocidades associadas ao seu rapto não passou de fantasias de José, o homem branco, perante a sexualidade do africano:

- Ao sentir-me presa por três negralhões, desmaiei! Mal dei acordo de mim, em dia claro, vejo-me rodeada de negros e de negras, falando sem os perceber! Reconheci o soba Canásse. [...] Havia uma cubata para mim onde dormia de sentinelas à porta. Dentro, uma preta sempre a rir-se só me entendia por gestos! [...] Tinha cama menos má, feita de mantas novas! Dentro da ilha andei à vontade! Era-me impossível fugir dali sem o auxílio de alguém. Vivia aflitíssima, receando pela tua vida... Por mim, percebi logo não terem intuitos assassinos! Tratavam-me bem! As minhas ralações eram, unicamente, por avaliar o teu desespero! (FIGUEIRA, 1935:310-311).

Contudo, a inquietação de José e as suas fantasias permanecem, mesmo depois de Josefina se encontrar sã e salva:

Fixo-a inúmeras vezes como se para mim tivesse ressuscitado! Nessas ocasiões, pensamentos estranhos me perturbam o cérebro, quase me irritam... sem no entanto ter motivo para tal! [...] Esteve prisioneira, sinto ciúmes por esses dias, roubados ao meu convívio! [...] no meu íntimo há instantes em que se trava luta cruel, me ocorre quanto lhe não poderiam ter feito, tendo-a prisioneira, da sua inteira vontade, dispondo dela como lhes aprouvesse!... [...] Esteve prisioneira dos selvagens, cativa forçada, num futuro de vida incerto, problemático, pensando sempre... em mim, no ente querido, no inseparável companheiro do lar! (FIGUEIRA, 1935:313-314).

Depois deste susto, José e Josefina, tal como o protagonista do romance anterior de Luís Figueira, vão apadrinhar o casamento de dois "Bons Selva- 
gens" que passam a servi-los com fidelidade. Referimo-nos a Sapálo, a exconcubina de Capitango, que se torna lavadeira dos padrinhos, e a António Santomista, no qual o trabalho forçado em São Tomé já incutira noções de "civilização", conferindo-lhe, não só a sagacidade e a coragem que utilizou no acto meritório de salvamento da patroa branca, mas também a capacidade de renunciar à poligamia ao desposar Sapálo:

- Um preto educado em São Tomé não é selvagem! Vive apenas com uma [mulher], imita os brancos! (FIGUEIRA, 1935:323).

Felizes por representarem um modelo cultural perante angolanos, seus servidores, José e Josefina desistem da "miragem africana" dos diamantes e instalam-se definitivamente em terras do Bailundo, prosseguindo em Angola, a par de outros colonos portugueses, a sua missão civilizadora.

\section{Referências bibliográficas:}

\section{Bibliografia Activa}

FIGUEIRA, Luís. Princesa Negra. O Preço da Civilização em África. Coimbra: Coimbra Editora, 1932, 428 p.

FIGUEIRA, Luís. Miragem Africana. O Preço da Civilização em África. Porto: Companhia Portuguesa Editora, 1935, 329 p.

\section{Bibliografia Passiva}

BONNICI, Thomas. O Pós-Colonialismo e a Literatura: estratégias de leitura. Maringá: Editora da Universidade Estadual de Maringá, 2000, 305 p.

CORTESÃO, Armando Zuzarte. Editorial. Boletim da Agência Geral das Colónias, Lisboa, Ano $1^{\circ}$, Nº1, Julho de 1925:3-9.

GALVÃO, Henrique. Em Terra de Pretos. Crónicas de Angola. Lisboa: Aillaud \& Bertrand, 1929, $199 \mathrm{p}$.

GALVÃO, Henrique. O Vélo d’Oiro (Romance Colonial). Lisboa: Parceria António Maria Pereira, 1933, 291 p.

GALVÃO, Henrique. O Sol do Trópicos (Romance Colonial). Lisboa: Edição do Autor, $1936,322 \mathrm{p}$.

GOMES, Aldónio e CAVACAS, Fernanda. Dicionário de Autores de Literaturas Africanas de Lingua Portuguesa. Lisboa: Editorial Caminho, 1997, 454 p. 
HEINTZE, Beatrix. Pioneiros Africanos. Caravanas de carregadores na África Centro-Ocidental (entre 1850-1890), Trad. Marina Santos. Lisboa: Editorial Caminho, 2004, 483 p.

HENRIQUES, Isabel Castro. O Pássaro do Mel. Estudos de História Africana. Lisboa: Edições Colibri, 2003, 239 p.

M’BOKOLO, Elikia. África Negra. História e Civilizações. Tomo I. Até ao Século XVIII, Trad. Alfredo Margarido. Lisboa: Editora Vulgata, 2003, 584 p.

M’BOKOLO, Elikia. Africa Negra. História e Civilizações. Tomo II. Do século XIX aos nossos dias, Trad. Manuel Resende, Revisão Científica de Alfredo Margarido e Isabel Castro Henriques. Lisboa: Colibri, 2007, 626 p.

MOURALIS, Bernard. As Contra-Literaturas, Trad. António Filipe Rodrigues Marques e João David Pinto Correia. Coimbra: Livraria Almedina, 1982, 227 p.

PÉLISSIER, René. História das Campanhas de Angola. Resistência e Revoltas, 1845-1941, Vol. I., Trad. Manuel Ruas. Lisboa: Editorial Estampa, 1986a, 397 p.

PÉLISSIER, René. História das Campanhas de Angola. Resistência e Revoltas, 1845-1941, Vol. II. , Trad. Manuel Ruas. Lisboa: Editorial Estampa, 1986b, 433 p.

PINTO, Alberto Oliveira. O Concurso de Literatura Colonial da Agência Geral das Colónias (1926-1951); Colonialismo e Propaganda, in Clio. Lisboa: Centro de História da Faculdade de Letras da Universidade de Lisboa, Nova Série, Vol. 7, 2002:191-256.

PINTO, Alberto Oliveira. O Retrato do Ambaquista em Uanga de Óscar Ribas: a angolanidade através da escrita ou a apropriação do discurso colonial português por um autor angolano?, in Actas do X Congresso Internacional ABRALIC 2006. Rio de Janeiro, 2006, http://www. abralic. org. br/cong2006/ListagemInscritos. asp.

SELVAGEM, Carlos. Literatura Portuguesa de Ambiente Exótico, in Boletim da Agência Geral das Colónias, Lisboa, Ano 2º No8, Fevereiro de 1926:3-16.

SHAKESPEARE, W. A Tempestade. Trad. João Grave. Porto: Lello \& Irmão Editores, s. d. , 151 p.

SHARPE, Jenny. Allegories of Empire. The Figure of Woman in the Colonial Text. Mineapolis \& London: University of Minnesota Press, 1993, 190 p.

SPURR, David. The Rhetoric of Empire. Colonial Discurse in Journalism, Travel Writing and Imperial Administration. Durban \& London: Duke University Press, 1993, 208 p.

TAGUIEFF, Pierre-André. La force du préjugé. Essai sur le racisme et ses doubles. Paris: Galimard, 1990, 644 p.

TRIGO, Salvato. Ensaios de Literatura Comparada Afro-Luso-Brasileira. Lisboa: Vega, s. d., 159 p.

Recebido em 11 de abril e aprovado em 16 de maio de 2010. 